\title{
PROFITABILITY AND CONSTRAINTS OF IFAD/VCD RICE PROJECT AMONG SMALLHOLDER FARMERS IN NIGER STATE OF NIGERIA
}

\author{
Sadiq, M.S ${ }^{1}$, Singh, I.P2 ., Ahmad, M.M³ ., Yunusa, J.B ${ }^{4}$. and Egba, S.M ${ }^{5}$. \\ ${ }^{1}$ Department of Agricultural Economics and Extension, FUD, Dutse, Nigeria \\ ${ }^{2}$ Department of Agricultural Economics, SKRAU, Bikaner, India \\ ${ }^{3}$ Department of Agricultural Economics, BUK, Kano, Nigeria \\ ${ }^{4}$ National Cereal Research Institute, Badeggi, Nigeria \\ ${ }^{5}$ Postgraduate Student, Department of Agricultural Economics, FUT, Minna, Nigeria \\ *corresponding author: sadiqsanusi30@ gmail.com (+2347037690123)
}

\begin{abstract}
Failure to sustain most of the rural poor and food security programmes in Nigeria after their life span is due to poor productivity of the capital investment of a project to generate a remunerative income to sustain a typical agrarian farming household in Nigeria. Thus, to critically investigate this hypothetical proposition, this research aimed at evaluating the viability of the IFAD rice project among the beneficiaries in Niger State of Nigeria. Undated data of the 2018 rainfed cropping season was elicited from 111 farmers through a multi-stage sampling technique and the information were collected viaa structured questionnaire complemented with an interview schedule. Both descriptive and inferential statistics were used to analyze the data collected. The empirical results showed that the rice project in the study area is likely not to be sustained after the stipulated time frame for the programme as inspite of the programme aim of doubling farmers' income viz. value chain. The capital investment is not productive to sustain an average farming household composed of 8 persons having an operational holding of less than two hectares. Therefore, the study recommends provision of consumption credit in addition to the production credit advanced to the farmers in order to make the capital investment viable so that its turnover after each production season will be consistently re-invested into the rice project and possibility of a farmer taken-up additional activities along the chain, thus keeping the business going concern viable and sustainable.
\end{abstract}

Keywords: Viability, Rice, IFAD Project, Niger State, Nigeria

http://dx.doi.org/10.21776/ub.agrise.2021.021.3.4

Received 13 February 2021

Accepted 25 July 2021

Available online 31 July 2021

\section{INTRODUCTION}

Andrea (2014), reported that globally, approximately 1.5 billion people are engaged in small-scale agriculture which includes $75 \%$ of the world's poorest people, whose food, income and livelihood prospects depend on agriculture. In Nigeria, peasantry has been the major mode of agricultural production and livelihood sustenance for over 70 percent of the population that is engaged in various agricultural activities as a career upon which the large non-farming population of the nation depends on for food security (Atala and Hassan, 2012).

Literature showed that poverty has been more prevalent among the food supplying rural populace which is majorly made up of smallholder farmers, as such agriculture still remains the major source of income to the rural poor (Schubert, 1994). Therefore, in Nigeria, it is impossible to achieve poverty reduction without rapid agricultural growth. In developing economies such as Nigeria, concern over the poverty surge and the need for its alleviation

CITATION: Sadiq, M., S., Singh, I., P., Ahmad, M., M., Yunusa, J., B., Egba, S., M., (2021). Profitability and Constraints of IFAD/VCD Rice Project Among Smallholder Farmers in Niger State of Nigeria, Agricultural Socio-Economics Journal, 21(3), 199-208 DOI: http://dx.doi.org/10.21776/ub.agrise.2021.021.3.4 
as a means of livelihood improvement has led to the conceptualization and implementation of various programmes in the world which aimed at poverty alleviation (Babatunde, 2006). Ashley and Maxwell (2011) as cited by Nxumalo and Oladele (2013), reported that the low performance of the agriculture sector does not only threatens the livelihood but it also affects the production capacity of the natural resources base, accelerates environmental degradation and fails to address poverty and malnutrition.

In order to enhance the performance of the agricultural sector, food security and poverty intervention programmes such as the International Fund for Agricultural Development-Value Chain Development (IFAD/VCD) was introduced in Nigeria. The programme is essentially peopleoriented as it supports the Nigerian Government's poverty reduction programme in rural areas with special focus on large numbers of smallholder farmers.

According to Chambers (1983) as reviewed by Kumba (2003) and cited by Etwire et al. (2013), in the past few decades, bottom-to-up approaches that view beneficiaries as partners, utilize the local experience and endeavour to empower target beneficiary have been promoted. This is because the developmental efforts that used the top-to-bottom approach with minimal input and involvement of target beneficiaries have long been recognized as an unsustainable and poor pathway to beneficiary empowerment and development.

The essence of the IFAD-VCD programme is to improve the livelihood of the rural populace particularly the vulnerable groups in order to enable them to escape the suicidal vicious cycle of poverty. The empowerment of rural poor communities to enable them identify their needs, implement a broad range of agricultural and rural development initiatives will bring about economic growth and development in the country. Most of the agricultural projects failed to be sustained due to poor capital investment productivity which is not remunerative to sustain the livelihood of the beneficiaries or target groups. Therefore, for the IFAD programme not to take a cue among the failed projects, it becomes very imperative to evaluate the viability of the capital investment of the farmers participating in the programme in Niger State of Nigeria. This research focused on the rice project as the state is well known for the production of rice in Nigeria. The broad objective of the study is to evaluate the viability of IFAD rice project among the participating farmers in the study area while the specific objectives were to estimate the profitability of the IFAD anchor rice project in the study area; to assess the motivating factors influencing participation in the rice project in the study area; and, to determine the problems affecting the farmers participating in the rice project in the study area.

\section{RESEARCH METHODOLOGY}

The study was conducted in Niger State of Nigeria and the state is located on latitudes $8^{\circ} 20^{\prime} \mathrm{N}$ and $11^{\circ} 30^{\prime} \mathrm{N}$ of the equator and longitudes $3^{\circ} 30^{\prime} \mathrm{E}$ and $7^{\circ} 20^{\prime} \mathrm{E}$ of the Greenwich Meridian time. The vegetation of the state is northern guinea savannah with sparse of southern guinea savannah. Agriculture is the major occupation in the study area and it's complemented with civil service jobs, artisanal, craftwork, Ayurveda medicines and petty trade. The present study relied on cross-sectional/undated data obtained from 111 rice farmers drawn viz. multi-stage sampling technique using the sampling frame obtained from IFAD-VCDP. In the state, only five (5) Local Government Areas were chosen as the pilot phase for the programme with Agricultural Zone A (Bida) and C (Kontagora) having two LGAs each namely Bida and Katcha; and, Wushishi and Kontagora respectively, while Zone $\mathrm{B}$ has one participating LGA viz. Shiroro. In the first stage, in Agricultural Zone A, one LGA viz. Katcha LGA was randomly selected; in Zone $\mathrm{B}$ the only participating LGA viz. Shiroro LGA was automatically selected; while in Zone C, Wushishi LGA was purposively selected based on its comparative advantage as rice is produce throughout the year owing to the presence of Tungan-Kawo irrigation dam. In the second stage, two villages were randomly selected from each of the chosen participating LGAs. Thereafter, two active cooperative associations from each of the selected villages were randomly selected. It is worth to note that Microsoft excel inbuilt random sampling mechanism was used for the random selections of the villages and the co-operative associations. In the last stage, using the sampling frame obtained from the IFAD/VCD office (Table 1), Cochran's formula was used to determine the representative sample size. Thus, a total of 111 active rice farmers form the sample size for the study. A structured questionnaire complemented with an interview schedule was used to elicit information from the respondents during the 2018 cropping season. The first objective was achieved using pseudo-profit function (cost concepts and income measures), the second objective was achieved using a measure of dispersion and Kendall's coefficient of concordance (KCC) model and the last objective was achieved using KCC model and exploratory factor analysis. The Cochran's formula used is shown below: 
$n_{a}=\frac{n_{r}}{1+\frac{\left(n_{r}-1\right)}{N}}$

$n_{r}=\frac{(1.96)^{2} p q}{e^{2}}$

Where:

$n_{a}=$ adjusted sample size for finite population

$n_{r}=$ sample size for infinite population
$N=$ population size

$\mathrm{p}=$ proportion of population having a particular characteristic

$\mathrm{q}=1-\mathrm{p}$

$e^{2}=$ error gap $(0.07)$

Thus, $\mathrm{p}=0.40$ and $\mathrm{q}=1-0.60=0.40$

Table 1: Sampling frame of participating and non-participating farmers

\begin{tabular}{|c|c|c|c|c|}
\hline LGAs & Villages & Co-operative Associations & SF & SS \\
\hline \multirow{4}{*}{ Katcha } & \multirow[t]{2}{*}{ Baddegi } & Managi Badeggi Farmers CMPS & 24 & 10 \\
\hline & & Aminci EbantiTwaki CMPS Ltd & 25 & 10 \\
\hline & \multirow[t]{2}{*}{ Edostu } & Edotsu Co-Operative Credit \& Marketing CMPS & 25 & 10 \\
\hline & & Edotsu Jinjin WugakunYema CMPS & 25 & 10 \\
\hline \multirow{4}{*}{ Shiroro } & \multirow[t]{2}{*}{ Baha } & Baha Abmajezhin Cooperative Multi-Purpose Society Ltd & 15 & 7 \\
\hline & & Abwanubo Najeyi Development Association & 18 & 8 \\
\hline & \multirow[t]{2}{*}{ Paigado } & Paigado Achajebwa Development Farmers Soc. & 25 & 10 \\
\hline & & Paigado Farmers Cooperative Society Ltd & 25 & 10 \\
\hline \multirow{4}{*}{ Wushishi } & \multirow[t]{2}{*}{ Bankogi } & Bankogi Alheri Farmers Coop. Multipurpose Soc Ltd & 22 & 9 \\
\hline & & Bankogi Gwari Nasara CMPS & 16 & 7 \\
\hline & \multirow[t]{2}{*}{ Kanko } & Kanko Arewa Farmers & 25 & 10 \\
\hline & & Kanko Unguwar Ndakogi Cooperative Multipurpose Society Ltd & 25 & 10 \\
\hline & & Total & 270 & 111 \\
\hline
\end{tabular}

Source: IFAD-VCDP farmers' database, 2018

Note: SF and SS mean sampling frame and sample size respectively.

\section{Empirical model}

\section{Cost concepts and Income measures}

The cost concepts and income measures developed by the Indian Commission of Agricultural Cost and Prices (CACP) and adopted by Subba et al., (2004; 2016) are specified below:

a. Cost Concepts: Costs related to sesame production are split up into various cost concepts such as $\mathrm{A}, \mathrm{A}_{1}, \mathrm{~B}$ and $\mathrm{C}$

Opportunity/Implicit cost: costs of self-owned and self-employed resource i.e. imputed cost

Accounting/Explicit cost: costs for purchasing and hiring of inputs and input services i.e. paid out costs/cash costs/ nominal/money cost

Economic cost: Opportunity cost + Accounting cost

Cost A: The following items are included in Cost A

Wages of hired labour

Market rate of fertilizers

Market rate of seeds

Market value of biocides

Land revenue, cess and other tax

Depreciation of farm implements

Interest on working capital

Miscellaneous expenses

Cost $A_{1}$ : Cost $A+$ rent paid for leased in land

Cost $\mathrm{B}$ : Cost $\mathrm{A}_{1}+$ interest on fixed capital excluding

land + rental value of owned land
Cost C: Cost B $+10 \%$ of TVC as management cost (Sidharth and Pankaj, 2012)

\section{b. Income Measures}

These are the returns over different cost concepts. Different income measures are derived using cost concepts. These measures are given below:

Farm business income $=$ Gross income - Cost $A_{1}$. (3)

Family labour income $=$ Gross income - Cost B....(4)

Net income $=$ Gross income - Cost $\mathrm{C}$

Farm investment income $=$ Farm business income Imputed value of family labour- Imputed management cost (OR) Net income + Imputed rental value of owned land

Return on Naira invested (ROI) =

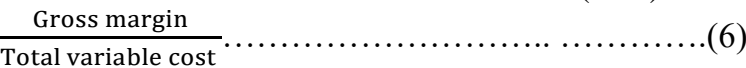

Rate of return on capital invested (RORCI) = Net farm income Total cost

Kendall's Coefficient of Concordance (W): Kendall's coefficient of concordance $(W)$ uses the $\chi^{2}$ statistic for testing. If the test statistic $W$ is 1 , then all the survey respondents have been unanimous and each respondent has assigned the same order to the list of subjects or situations. If $W$ is 0 , then there is no 
overall trend of agreement between the respondents and their responses may be regarded as essentially random. Intermediate values of $W$ indicate a greater or lesser degree of agreement among the various respondents. Following Sadiqet al.(2017), Kendall's coefficient of concordance developed by Kendall and Smith (1939); Wallis (1939) is given below:

$W=\frac{12 S}{k 2 n(n 2-1)-k T}$

Where;

$\mathrm{S}=$ Sum over all subjects

$\mathrm{k}=$ Number of respondents ranking the attributes or objects

$\mathrm{n}=$ Number of attributes or objects that are evaluated by respondents

$$
\mathrm{T}=\text { Tie-correction factor }
$$

$T=\sum\left(t_{k}^{3}-t_{k}\right)$

' $t_{k}{ }^{\prime}$ is the number of tied ranks in each (k) of $\mathrm{g}$ groups of ties. The sum is computed over all groups of ties found in all $\mathrm{m}$ variables of the data table. $\mathrm{T}$ is 0 when there are no tied values.

The $\mathrm{Chi}^{2}\left(\chi^{2}\right)$ statistic is given as follow:

$\chi^{2}=k(n-1) W$

Where;

$\mathrm{k}=$ Number of respondents

$\mathrm{n}=$ Number of objects or attributes being ranked

$W=$ Kendall's coefficient of concordance (KCC)

Friedman's Chi-square Statistic: Friedman's Chisquare statistic proposed by Friedman (1937) was developed primarily to test the hypothesis that the ratings assigned to subjects under investigation come from the same statistical population. This is an indirect way of evaluating the extent of agreement among raters. Due to its close mathematical relationship with Kendall's coefficient of concordance $(W)$ it is used in studies of inter-judge reliability. Friedman's Chi-square statistic is given below:

$\chi_{r}^{2}=k(n-1) W$

Where;

$\chi_{r}^{2}=$ Friedman's chi ${ }^{2}$ statistic

$\mathrm{k}=$ Number of respondents

$\mathrm{n}=$ Number of objects or attributes being ranked

$W=$ Kendall's coefficient of concordance (KCC)

Grand mean $(\bar{X})=\frac{\sum_{i=1}^{n} \bar{X}}{n}$

$X^{-}=$mean $; n=$ total number of statements

Perception index $=\frac{\text { Grandmean }}{\text { Likertscaleno Likert scale value }}$

\section{RESULTS AND DISCUSSION \\ Cost and Income Structures of Rice Production}

A perusal of the Table showed the incurred economic cost of cultivation to be $\$ 158793.60$ with the working and fixed capital costs been $\$ 127676.1$ $(80.40 \%)$ and $\$ 31117.52(19.60 \%)$ respectively (Table 2). However, a review of the cost implication from an accounting point of view, the cost of cultivation, working and fixed capital costs plummeted to $\$ 1794.36, \$ 88658.55$ (96.58\%) and N3135.82 (3.42\%) respectively. In addition, the economic cost of production stood at $\$ 43.83$ while the money cost of production plummeted to $\$ 32.89$. Furthermore, the accrued economic revenue cum gross margin and net income were \$543429.60, $\$ 415753.50$ and $\$ 384636.00$ respectively. Though, the farm business income, family labour income and farm investment income were $\$ 41421.10$, $\$ 436421.10$ and $\$ 389636.00$ respectively. Thereafter, it can be deduced from the income measures that for every $\$ 1$ invested a profit of $\$ 2.26$ kobo will be gain and the $\$ 1$ incurred will be returned as indicated by the RONI index value of 3.26. Thus, a profit of $69.04 \%$ was gained. The RORCI index value of 2.45 showed that the investment in the long-run is solvent i.e. has the ability to defray its liabilities. Therefore, money markets are advised to advance credit to these farmers as their capital base is capable of defraying the principal and interest as the $59.09 \%$ gain will liquidate the principal of $30.71 \%$ plus the interest rate of $8 \%$, thus leaving a farm with $20.38 \%$ gain on capital invested. Therefore, it can be inferred that the IFAD rice project from business point of view is worth investing in and participating in as the rice venture is very profitable but from the economic point of view it cannot sustain an average household size of 8 persons as the monthly income per household head translate into $\$ 32053.00$ (\$104.07). Consequently, it will amount to $\$ 4006.63$ (\$13.01) per head/month in the household, which will translate to $\$ 0.43$ ( $\$ 133.55$ ) per day, thus far below the FAO recommended $\$ 1.9$ for required calorie intake per head/day for sub-Saharan Africa. Therefore, the programme should incorporate consumption credit so as to make the capital investment productivity in order to achieve her major goal of food security for the subsistence farming household and sustainability of the programme after the life span of the programme. 


\section{Motivational Factors Influencing Participation in the Study Area}

Using the mean rank of the Kendall's coefficient of concordance (KCC), a cursory review of the results showed the most important factors that influenced farmers' participation in the programme to be motivation given by the change agents $\left(1^{\text {st }}\right)$, provision of subsidized inputs $\left(2^{\text {nd }}\right)$, assurance of offtakers $\left(3^{\text {rd }}\right)$, access to training $\left(4^{\text {th }}\right)$ and access to market information $\left(5^{\text {th }}\right)$ (Table 3$)$. However, the identified least influencing factors were nonprofitability of other interventions $\left(11^{\text {th }}\right)$ and the size of the operational holding $\left(12^{\text {th }}\right)$. Thus, it is very obvious that the programme goal of enhancing livelihood status and food security of subsistence farming households had resound acceptability in the study area. Furthermore, the KCC value of 0.68 implies that there is good concordance or agreement among the farmers with regard to this ranking of the factors influencing their participation. In addition, the significance of Friedman's $\mathrm{Chi}^{2}$ at $1 \%$ degree of freedom indicates that the assigned attributes to the motivational factors by the farmers came from the statistical population.

Table 3: Motivational factors influencing participation

\begin{tabular}{|c|c|}
\hline Factors & Mean rank \\
\hline Motivation by extension workers & 7.15 \\
\hline Subsidized quality inputs provided by IFAD & 7.10 \\
\hline Access to market information & 6.71 \\
\hline Links with processors & 6.28 \\
\hline Opportunity to add value to produce and generate more revenue & 6.66 \\
\hline Non-profitability of other interventions & 5.73 \\
\hline Membership of farmers' organization & 6.17 \\
\hline Enhanced income level & 6.44 \\
\hline Access to credit facilities & 6.39 \\
\hline Land size cultivated & 5.68 \\
\hline Access to training & 6.82 \\
\hline Assurance of off-takers & 6.88 \\
\hline Kendall's coefficient (KCC) & 0.68 \\
\hline $\operatorname{KCC~Chi}{ }^{2}\left(\chi^{2}\right)$ & $\mathbf{7 7 . 8 1} * * *$ \\
\hline Friedman's Chi ${ }^{2}\left(\chi^{2}\right)$ & $\mathbf{7 7 . 8 1} * * *$ \\
\hline
\end{tabular}

Source: Field survey, 2018

\section{Perceived Constraints Affecting IFAD Farmers}

A perusal of the Table showed the major barriers confronting the farmers participating in the programme to be sharp practices/irregularities of change agents viz. extortion and financial exploitation $\left(1^{\text {st }}\right)$, inadequate access to improved rice varieties viz. poor availability of licensed agro-seed vendors $\left(2^{\text {nd }}\right)$, inadequate extension service delivery $\left(3^{\text {rd }}\right)$, scarcity of farm inputs also owing to poor availability of licensed agro-vendors $\left(4^{\text {th }}\right)$ and poor coordination among the actors involved in the value chain $\left(5^{\text {th }}\right)$. Inadequate processing material was the only identified perceived moderate constraint affecting the participants as it had a mean value equal to the Likert scale benchmark $(\bar{X}=3.50)$. However, the programme participants perceived inadequate counterpart fund contribution and inadequate financing to be the lesser constraints. Thus, it can be suggested that there is no much problem of an administrative bottleneck in the release of funds by the programme organizers in the state to the target group. The grand mean value $(3.66 \pm 0.353)$ been higher than the Likert scale mean value $(3.5 \pm 1.87)$, imply that most of the farmers had negative or unfavourable perception with respect to the identified problems affecting them in the rice production project in the study area. Also, the constraint index value of 0.61 implies that $61 \%$ of the farmers had unfavourable disposition with respect to the problems identified to be affecting them in rice production in the study area (Table 4).

The significance of the estimated value of the KCC index (0.70) at $1 \%$ degree of freedom indicates that there is concordance or agreement among the farmers with respect to the ranking of the constraints affecting them in rice production in the study area. In addition, the significance of Freidman's test at less than $1 \%$ probability level means that the attributes assigned to the constraints by the farmers came from the statistical population. Therefore, it is suggested that the programme policymakers should tacitly use this ranking to address the problems affecting the rice production project in the study area (Table 4). 
Furthermore, a perusal of the Table showed the rotational analysis to be suitable as the KMO value is 0.898 , a meritorious level, and is above the Kaiser recommended value of 0.50 , thus the adequacy of the sample for the analysis. A value of "zero" means that the sum of partial correlation is large relative to the sum of correlation, implying diffusion in the pattern of correlation; hence, factor analysis is likely to be inappropriate. While a value close to "one" indicates that the patterns of the correlations are relatively compact, thus factor analysis will yield distinct and reliable factors (Sadiqet al., 2018). In addition, the original correlation matrix is not an identity matrix as evident by Bartlett's Test of Sphericity which is significant at less than $1 \%$ degree of freedom. For factor analysis to work, there is a need for some relationships between variables because if the R-matrix is an identity matrix, then all the correlation coefficients will be zero.

For the principal factor analysis, the varimax rotation reduced the perceived constraints to an interpretable four factors as evident by their respective Eigen value which is above 1. The existence of internal consistency between the factor loadings for each of the four (4) factors was observed as indicated by each rotated factor Cronbach's Alpha values which were greater than the recommended value of 0.70 as posited by Nunnaly (1978) and cited by Purnomo and Lee (2010). However, Churchill (1979) suggested a cut-off point of 0.60 to be appropriate for exploratory research. The behaviour of individual items in relation to others within the same factor provides confirmation of content validity because the highest factor loading is central to the domains assessed by these factors (Francis et al., 2000).

The extracted four factors accounted for $70.099 \%$ of the total variance which is above the percentage recommended to be satisfactory for social science research by Hair et al.(1998) as cited by Bagheri and Fami (2016).The extracted factors exclude those factors loadings whose values were less than 0.40 . Thereafter, the four extracted factors were labeled as 'production and social constraints', 'market and extension constraints', 'technological constraint' and 'financial constraint'. Factor 1 (F1), named 'production and social constraints', highly loaded from ten-factor loadings and accounted for $47.58 \%$ of the total variance showed farmers concern on time and form utilities, land tenure problem and illiteracy. Therefore, this called for the provision of scientific storage facilities and farmers field schools in the studied area to address these constraints. Factor 2 (F2), named 'market and extension constraints', which explained $11.52 \%$ of the total variance and loaded from seven factor loadings showed farmers concern on market imperfections and ineffectiveness of change agents, and thus the study call for interventions viz. input subsidies and farmer to farmer extension approach to tackle this constraints affecting rice production in the studied area. Factor 3 (F3), named 'technological constraint', loaded from three factor loadings and explained $6.31 \%$ of total variance, revealed farmers worry on inadequate availability of improved seed varieties, and thus the study call for creation of adequate and proper input link in the chain viz. licensing some of the farmers as agro-seed dealers and providing them with adequate credit for seed marketing in the study area. The $4^{\text {th }}$ Factor (F4), named "Financial constraint", loaded from three factor loadings and accounted for $4.69 \%$ of the total variance, showed farmers concern on the effect of capital paucity on rice production and thus call for the need to provide consumption credit apart from the production credit in order to make the production credit productive so as to generate a remunerative turnover that will enhance the solvency status of their enterprise in the study.

\section{CONCLUSION AND RECOMMENDATION}

Inspite of the programme packages that motive good participation in the IFAD programme in the study area, it can be inferred that the rice production project anchor by the programme in the study area is likely not to be sustainable in the longrun as the gained profit from the capital investment is not productive or remunerative to sustain an average subsistence farming household composed of 8 persons having less than two hectares of farm. In addition, four factors viz. production and social constraints, market and extension constraints, technological constraint and financial constraint were empirically established to be the constraints affecting the rice project in the study area. Therefore, it was recommended that in addition to the production credit advanced to the farmers, consumption credit should be advanced to the farmers so as to make the capital investment productive so that its turnover will be consistently re-invested into the business instead of being feasted by capital consumption items.

\section{REFERENCES}

Andrea, B.(2014).Linking Smallholder Farmers to Markets and the Implication for Extension and Advisory Services. MEAS Discussion

Paper No. 4. United State Agency for International Development. 
Ashley, C. and Maxwell, S.(2001).Rethinking rural development. Development Policy Review, 19(4):395-425.

Atala, T.K. and Hassan, M.B.(2012).Adopted Village Concept and Vision 20:2020. Paper presented at the North West Zonal REFILS Workshop, held at the Institute for Agricultural Research, Ahmadu Bello University, Zaria. 23-24 Feb. 2012.

Babatunde, O.(2006).Differential poverty reduction impact of small-scale irrigated development between its beneficiaries and non-beneficiaries in Nigeria. Technical Report on the Agropolis Award

Bagheri, A. and Fami, H.S.(2016).Potato growers' risk perception: A case study in Ardabil

Chambers, R.(1983).Rural development: Putting the last first. Essex. Addison Wesley Longman Limited

Churchill, G.A.(1979).A Paradigm for Developing Better Measures of Marketing Constructs. Journal of Marketing Research, 16(1):64-73

Etwire, P.M., Dogbe, W.,Wiredu, A.N., Martey, E., Etwire, E., Owusu, R.K. and Wahaga, E. (2013).Factors influencing farmer's participation in agricultural projects: The case of the Agricultural Value Chain Mentorship Project in the Northern Region of Ghana. Journal of Economics and Sustainable Development, 4(10):36-43

Francis, L., Katz, Y. and Jones, S.(2000).The reliability and validity of the Hebrew version of the computer attitude scale. Computer Education, 35(2):149-59.

Friedman, M.(1937).The use of ranks to avoid the assumption of normality implicit in the analysis of variance. Journal of American Statistical Association, 32(200):675

Hair, J.F., Anderson, R.E., Tatham, R.L. and Black, W.C.(1998).Multivariate DataAnalysis, $5^{\text {th }}$ Edition.Prentice Hall, Upper Saddle River, NJ.

Kendall, M.G. and Smith, B.B.(1939a).On the method of paired comparisons. Biometrica, 31(3:4):324-345

Kendall, M.G. and Smith, B.B.(1939b).The problem of $m$ ranking. The Annals of Mathematical Statistics, 10(3):275-287

Kumba, F.F.(2003).Farmer participation in agricultural research and extension service in Namibia. Journal of International Agricultural and ExtensionEducation, 10(3):47-55

Nunnaly, J.C.(1978).Psychometric Theory, 2nd ed., McGraw Hill, New York.
Nxumalo, K.K.S. and Oladele, O.I.(2013).Factors affecting farmers'participationin Agricultural Programme in Zululand District, Kwazulu Natal Province, South Africa. Journal of Social Science, 34(1):83-88.

Province of Iran.Journal of Agricultural Science Technology, 18:55-65

Purnomo, S.H. and Lee, Y.(2010).An assessment of readiness and barriers towards ICT programme implementation: Perceptions of agricultural extension officers in Indonesia. International Journal of Education and Development using Information and Communication Technology, 6(3), 19-36

Sadiq, M.S., Singh, I.P., Ahmad, M.M., Lawal, M., Kamaldeen, N. and Sani, T.P. (2018).Determining the perceived constraints affecting cassava farmers in Kwara State of Nigeria. FUDMA Journal of Agriculture and Agricultural Technology, 4(2):235-247

Sadiq, M.S., Singh, I.P., Isah, M.A., Greima, I.J. and Umar, S.M.(2017).Strategy of minimizing the cost of cultivation vis-à-vis boosting farm income of small-holder maize farmers in Niger State of Nigeria using Efficiency Measurement System (EMS). Indian Journal of Economics and Development, $17(2 \mathrm{a}): 722-728$

Schubert, R.(1994).Poverty in developing countries, its definition, extent and implications. Economics, Vol. 49/50.

Sidhart, B. and Pankaj, K.S.(2012).Agricultural economics at glance. Sharma publisher and distributors, New Delhi, India

Subba, R.S., Raghu, R.P., Neelakanta, S. T. A. and Bhavani, D.I.(2016).Agricultural Economics First Edition. Oxford and IBH publishing company PVT. Limited, New Delhi, India

Subba, R.S., Raghu, R.P., Neelakanta, S. T. A. and Bhavani, D.I.(2004).Agricultural Economics Second Edition. Oxford and IBH publishing company PVT. Limited, New Delhi, India

Wallis, W.A.(1939).The correlation ratio for ranked data. Journal of the American Statistical Association, 3(207):533-538 
Table 2: Cost concepts and income measures per hectare of rice farm

\begin{tabular}{|c|c|c|c|c|c|}
\hline Items & Quantity & Unit price & Amount (N) & Items & Amount (N) \\
\hline Variable costs & & & & Cost concepts & \\
\hline Seeds & 39.05 & 355 & 13861.50 & Total variable accounting cost & 88658.55 \\
\hline NPK & 173.62 & 160 & 27778.54 & Total fixed accounting cost & 3135.82 \\
\hline Urea & 95.69 & 160 & 15311.00 & Total accounting cost & 91794.36 \\
\hline Insecticides & 0.27 & 1000 & 273.41 & Total variable economic cost & 127676.10 \\
\hline Pesticides & 0.06 & 3000 & 184.55 & Total fixed economic cost & 31117.52 \\
\hline Herbicides & 3.73 & 1500 & 5598.09 & Total economic cost & 158793.60 \\
\hline Family labour & 48.77 & 800 & 39017.53 & Cost A1 & 102008.50 \\
\hline Hired labour & 32.06 & 800 & 25651.46 & Cost B & 107008.50 \\
\hline Interest on working capital(imputed) & 127676.10 & $8 \%$ & 10214.09 & Cost $\mathrm{C}$ & 158793.60 \\
\hline Total variable cost & & & 127676.10 & Income measures & \\
\hline Fixed costs & & & & Accounting revenue & 418626.10 \\
\hline Depreciation on capital items & 3135.82 & $20 \%$ & 3135.82 & Economic revenue & 543429.60 \\
\hline Rental value of owned land & 1 & 5000 & 5000 & Farm business income & 441421.10 \\
\hline Imputed managerial cost & 127676.10 & $10 \%$ & 12767.61 & Family labour income & 436421.10 \\
\hline Total fixed cost & & & 31117.52 & Economic gross margin & 415753.50 \\
\hline Total cost (TC) & & & 158793.60 & Economic net farm income & 384636.00 \\
\hline Returns & & & & Farm investment income & 389636.00 \\
\hline Quantity sold & 2790.84 & 150 & 418626.10 & RONI & 3.26 \\
\hline Quantity gifted & 378.85 & 150 & 56826.73 & RORCI & 2.45 \\
\hline Quantity consumed & 453.18 & 150 & 67976.76 & Cost of production (Accounting) & 32.89 \\
\hline Total output quantity & 3622.86 & 150 & 543429.60 & Cost of production (Economic) & 43.83 \\
\hline Total revenue (Accounting) & & & 418626.10 & & \\
\hline Total revenue (Economic) & & & 543429.60 & & \\
\hline
\end{tabular}

Source: Field survey, 2018 
Table 4: Constraints affecting IFAD farmers

\begin{tabular}{|c|c|c|c|c|c|}
\hline Constraints & Mean & F1 & F2 & F3 & F4 \\
\hline Inadequate storage facilities & $3.71\left(8^{\text {th }}\right)$ & 0.799 & & & \\
\hline High illiteracy level & $3.43\left(15^{\text {th }}\right)$ & 0.797 & & & \\
\hline Poor storage facilities for harvested crops & $3.71\left(8^{\text {th }}\right)$ & 0.791 & & & \\
\hline Land tenure problem & $3.71\left(8^{\text {th }}\right)$ & 0.778 & & & \\
\hline Cultural influence on access and use of some technologies & $3.79\left(6^{\text {th }}\right)$ & 0.743 & & & \\
\hline Poor road network & $3.17\left(17^{\text {th }}\right)$ & 0.742 & & & \\
\hline Labour scarcity and supply problem & $3.55\left(11^{\text {th }}\right)$ & 0.695 & & & \\
\hline Difficulty in leasing /renting of farm land & $3.91\left(5^{\text {th }}\right)$ & 0.673 & & & \\
\hline Inadequate processing materials & $3.50\left(14^{\text {th }}\right)$ & 0.639 & & & \\
\hline Poor access to market information & $3.66\left(10^{\text {th }}\right)$ & 0.559 & & & \\
\hline High cost of farm inputs & $3.51\left(13^{\text {th }}\right)$ & & 0.782 & & \\
\hline Lack of standardization in the unit of measurement & $3.94\left(4^{\text {th }}\right)$ & & 0.756 & & \\
\hline High transaction costs & $3.52\left(12^{\text {th }}\right)$ & & 0.727 & & \\
\hline Irregularity of extension services & $4.13\left(1^{\mathrm{st}}\right)$ & & 0.718 & & \\
\hline High cost of processing & $3.77\left(7^{\text {th }}\right)$ & & 0.711 & & \\
\hline Price fluctuation & $3.71\left(8^{\text {th }}\right)$ & & 0.583 & & \\
\hline Inadequate extension services & $4.09\left(2^{\text {nd }}\right)$ & & 0.564 & & \\
\hline Poor coordination among the actors in the value chain & $4.01\left(3^{\text {rd }}\right)$ & & 0.497 & & \\
\hline Inadequate access to improved seed varieties & $4.13\left(1^{\mathrm{st}}\right)$ & & & 0.743 & \\
\hline Inadequate quantity of improved seed varieties & $3.91\left(5^{\text {th }}\right)$ & & & 0.726 & \\
\hline High cost of improved seed varieties & $3.70\left(9^{\text {th }}\right)$ & & & 0.568 & \\
\hline Inadequate counterpart funding by the state government & $2.69\left(19^{\text {th }}\right)$ & & & & 0.815 \\
\hline Farmers' organization inability to meet-up with the matching grant requirement & $3.25\left(16^{\text {th }}\right)$ & & & & 0.715 \\
\hline Inadequate financing & $2.98\left(18^{\text {th }}\right)$ & & & & 0.626 \\
\hline Grand mean & 3.66 & & & & \\
\hline Perception index & 0.61 & & & & \\
\hline Kendall's coefficient (KCC) & 0.701 & & & & \\
\hline $\mathrm{KCC} \mathrm{Chi}^{2}\left(\chi^{2}\right)$ & $314.80 * * *$ & & & & \\
\hline Friedman's Chi' ${ }^{2}\left(\chi^{2}\right)$ & $314.80 * * *$ & & & & \\
\hline Eigen-value & & 11.894 & 2.880 & 1.578 & 1.172 \\
\hline \% of variance (Extraction) & & 47.576 & 11.521 & 6.312 & 4.689 \\
\hline Cronbach's Alpha & & .934 & .910 & .914 & .755 \\
\hline Kaiser-Meyer-Olkin test & 0.898 & & & & \\
\hline Bartlett's Test of Sphericity $\left(\chi^{2}\right)$ & $2282.67 * * *$ & & & & \\
\hline
\end{tabular}

Source: Field survey, 2018. Note: value in ( ) is rank and Base line mean $(\bar{X})=3$ 
This page is intentionally left blank 